\title{
Characteristics of B2B adoption and planning of online marketing communications
}

Received: 6th April, 2006

\section{Morten Bach Jensen}

is a senior business researcher at the Danish industrial pump manufacturer Grundfos. He is also affiliated as an industrial PhD-fellow with both the IT University of Copenhagen and Copenhagen Business School. Throughout the last 12 years, he has been working in marketing at large industrial companies, in teaching and academia, as well as at a larger consultancy firm. Morten holds a BSc in Engineering and an MSc in IT.

\begin{abstract}
This paper addresses the issue of whether there is a need for better online marketing communication planning and prioritisation methods, particularly for B2B companies. It describes the result of an empirical study among larger Danish companies. The work looks at differences between B2C and B2B companies, regarding the importance of offline and online marcom disciplines, online spending and usage of methods for online communication prioritisation. The paper concludes that due to high online spending, a less specialised priority of online disciplines and very limited usage of existing methods, B2B companies need to be on the lookout for new systematic methods for online communication planning.
\end{abstract}

Morten Bach Jensen IT University of Copenhagen Rued Langgaards Vej 7 DK-2300 Copenhagen Denmark

Tel: +452988 1669 Fax: +45 72185001 email: mbj@itu.dk

\section{INTRODUCTION}

The increasing adoption of online media raises the question of whether existing marketing prioritisation and planning methods can accomplish the progressively more complex planning task. B2B companies without a strong tradition of quantifiable media planning may particularly find a need for more systematic and holistic methods. As is the case offline, the importance attributed to online marcom disciplines differs between $\mathrm{B} 2 \mathrm{C}$ and $\mathrm{B} 2 \mathrm{~B}$ companies. Where B2C marketers find mass communication disciplines such as online display advertising and sales promotion more important, B2B companies prefer relational building disciplines such as online events and product demonstrations. Even though there are differences, B2B companies seem to have a less specialised approach online, hence discrimination is not as strong online as offline. In general, B2B companies spend a much larger proportion of their budget on online activities than B2C companies. In contrast, higher-spending $\mathrm{B} 2 \mathrm{~B}$ companies have a significantly lower usage of systematic methods for planning and prioritising of their online spending. Whereas $\mathrm{B} 2 \mathrm{C}$ companies to some extent seem to rely on advertising planning criteria, eg reach-frequency, B2B companies lack planning and prioritisation methods for online marcom. This paper argues for better online marcom planning and prioritisation methods, especially for B2B companies. In doing so, it compares the importance of marcom disciplines between $\mathrm{B} 2 \mathrm{~B}$ and $\mathrm{B} 2 \mathrm{C}$ 
companies, examining spending as well as usage of existing methods for planning and prioritisation.

\section{HYPOTHESES}

Online marcom has not been properly integrated as part of the marketing mix, and is therefore far from fully utilised. ${ }^{1}$ In part, this might be due to the fact that online marcom does not have the same long tradition of media and communications planning as offline communication. ${ }^{2}$ Further, one could argue that this is a particular concern within $\mathrm{B} 2 \mathrm{~B}$ marketing, where the more 'qualitative' relationship marketing paradigm has been predominant for at least a decade. ${ }^{3}$ One would naturally expect that online marcom, due to its unique targeting and personalisation possibilities, has a high potential within $\mathrm{B} 2 \mathrm{~B}$ marketing. The issue, however, is how to plan and prioritise online marcom. This text will try to answer the question of whether there is a need for better online marcom planning and prioritisation methods, in particular for $\mathrm{B} 2 \mathrm{~B}$ companies. In the effort to do so, differences in how $\mathrm{B} 2 \mathrm{C}$ and $\mathrm{B} 2 \mathrm{~B}$ use individual marcom disciplines will be investigated. Moreover, the paper analyses how online marcom is allocated in existing as well as projected future budgets. The hypotheses below have consequently been formulated.

B2B companies often have a more specific target and subsequently a more focused communication. Thus, the relationship marketing paradigm seems to have more appeal and relevance within B2B. B2C companies often communicate to the masses, and in this case, mass communication as advertising is more relevant. This seems obvious within traditional offline marcom, where a wide range of disciplines is available. However, within online marcom there can also be found a wide range of different disciplines, from mass communication to more personal activities, ${ }^{4}$ and it could be argued that the same differentiation can be observed here.

$$
\begin{aligned}
& \mathrm{H}_{1} \text { : } \text { The focus on both offline and } \\
& \text { online marcom disciplines differs } \\
& \text { between B2B and B2C } \\
& \text { companies. Where B2C prefers } \\
& \text { mass communication, B2B } \\
& \text { considers personalised and } \\
& \text { relational disciplines more } \\
& \text { important. }
\end{aligned}
$$

Even though online marcom has been argued to cover a wide range of both mass and personal (relational) disciplines, the immediate appeal of online communication is often its targeting and personalisation capabilities. Whereas mass communication is extensively covered by existing media, online communication fills an obvious gap within relationship marketing and should have a strong appeal to B2B marketers. In a recent multinational study, Barwise and Farley showed that B2B companies generally spend a higher percentage of their budget on interactive marketing. ${ }^{5}$ Therefore, B2B companies are presumed to spend a larger amount of their budget on online activities compared with $\mathrm{B} 2 \mathrm{C}$ companies, both now and in the future.

$$
\begin{aligned}
\mathrm{H}_{2 \mathrm{a}}: & \mathrm{B} 2 \mathrm{~B} \text { companies spend a larger } \\
& \text { portion of their total budget } \\
& \text { online than B2C companies. } \\
\mathrm{H}_{2 \mathrm{~b}}: & \mathrm{B} 2 \mathrm{~B} \text { companies will continue to } \\
& \text { spend a larger portion of their } \\
& \text { total budget online than B2C } \\
& \text { companies. }
\end{aligned}
$$

One would expect that B2C communication with its strong tradition of media planning ${ }^{6}$ would extend this tradition into online marcom prioritisation. B2B marcom prioritisation, 
however, has never been that quantifiable and systematic, and this lack of best practice could be expected to have an impact on online marcom prioritisation and planning.

$\mathrm{H}_{3}$ : B2B companies use systematic methods for planning and prioritising online marcom significantly less than $\mathrm{B} 2 \mathrm{C}$ companies.

\section{DATA COLLECTION AND METHODOLOGY}

Data were collected from a selection of Danish companies with more than 200 employees. Larger companies were chosen, as it was expected that the usage of marcom, online and offline, would be more established within this group. Data was drawn from the CD-direct database (based on the Danish Central Business Register). The total number of companies in the database was 781 , but due to redundancies and misplacements etc, it was reduced to 674. A total of 205 respondents answered the questionnaire, equivalent to 30 per cent of the cleaned database. Unfortunately, only 134 respondents were able to classify their company as either $\mathrm{B} 2 \mathrm{~B}$ or B2C, but this still counts for approximately 20 per cent of the cleaned database. Although the sample was heavily skewed, with $108 \mathrm{~B} 2 \mathrm{~B}$ and 26 $\mathrm{B} 2 \mathrm{C}$ respondents, according to the central limit theorem, both groups are still large enough to justify the assumption of mean values following a normal distribution. ${ }^{7}$ The 674 companies were initially contacted by post in December 2005, asking the marketing manager to answer an online questionnaire. As this gave far below 100 respondents, the remaining companies were next contacted by phone in January 2006 asking for the person in overall charge of marketing. If that person was unavailable, their email address was requested. Finally, all companies where personal email addresses had been acquired were contacted with a link to an online questionnaire. An incentive was provided in terms of the possibility to sign up for a free descriptive report on the data. Sixty-three per cent of the respondents were either marketing managers or marketing director, 18 per cent ticked off marketing coordinator or marketing responsible, 9 per cent ticked off product manager, web responsible, communication manager or communication director and the remaining 10 per cent were classified under other. Taking the variation in terminology in different companies into account, the sample seems to have met the recruitment criteria reasonably. Furthermore, only 12 per cent of the respondents had been employed for less than 1 year, whereas 72 per cent had been employed for more than 3 years.

Questions were primarily asked on a five-point Likert scale with individual wording, defining 3 as the neutral value. The two measures related to the present and future budget allocation of online marcom were asked on an 11-point scale with increasing budget percentage intervals.

All measures were mean evaluated with independent-samples $t$-test $(p<0.1)$. The test was based on significance of Levene's test for equality of variances $(p<0.05)$ carried out assuming either equal variances or non-equal variances. Investigating the existence of a general discrimination function between $\mathrm{B} 2 \mathrm{C}$ and $\mathrm{B} 2 \mathrm{~B}$ companies for online as well as offline marcom, discriminant analysis and logistic regression were applied on the measures in relation to $\mathrm{H}_{1}$. The appropriateness of discriminant analysis was judged by non-significant Box-M $(p>0.05)$ and significance of Wilks' 
lambda in the canonical discriminant function $(p<0.05)$.

The logistic regression was evaluated on a good model of fit statistics (Cox and Snell $\mathrm{R}^{2}$ and Nagelkerke $\mathrm{R}^{2}$ ); ie between 0.3 and 0.5 as argued to be excellent by Lattin and Green. ${ }^{8}$ Further, testing for non-significance was made by the Hosmer-Lemeshow test $(p>0.05)$. Finally, the variables included in the equation were tested to be significant at a 10 per cent significance level.

\section{DEFINITION OF MEASURES}

Offline marcom measures are based on extant integrated marketing communication (IMC) literature. ${ }^{9-15}$ IMC is a concept of marketing communications that recognises the added value in integrating all communication disciplines. The number of disciplines originates from the four classical disciplines: ${ }^{16}$ advertising, sales promotion, public relations and personal selling. Over time, multiple authors have been adding new disciplines to the concept. Based on the references above, nine disciplines were included in this paper. Packaging is mentioned as an individual discipline by one author, but was not included, as it is not generally accepted as an individual IMC discipline. Furthermore, events and exhibitions and trade fairs were aggregated into a single discipline. This leads to the following nine disciplines: advertising, sales promotion, direct marketing, sponsorship, public relations, events and exhibitions, relationship marketing, point-of-purchase marketing and sales supporting activities.

While offline marcom is divided quite concisely into disciplines in extant literature, few attempts have been made to create a distinct online marcom typology. ${ }^{17}$ However, both IMC

literature as well as more specific online literature recognises that online marcom includes multiple activities. ${ }^{18-\frac{1}{2} 5}$ It was therefore considered appropriate to develop online marcom measures, not on the IMC discipline level, but in relation to the activities mentioned in said literature. The 17 online marcom activities found are briefly described below.

- Display advertising such as banners, pop-ups and interstitials. These have proven to be very competitive in comparison with offline advertising. ${ }^{26-28}$

- Search engine advertising/marketing (SEA/SEM) including both organic and paid optimisation. Organic SEM refers to achieving good search rankings for a website without paying for it. Paid SEA/SEM is maybe best known in the form of Google adwords, but other services exist such as Overture. ${ }^{29}$ Smith $^{30}$ shows in a European Jupiter Research report that paid search on average has exceeded display advertising as the most predominant online advertising format.

- Public relations primarily refers to the support and monitoring of online media relations. Macleod ${ }^{31}$ mentions five best practice parameters to consider when implementing online media relations: supply time critical information (eg financial information) in real time; apply a 'Net-friendly', not corporate tone of voice; enable full transparency and openness with data and content; monitor and evaluate non-corporate views on the firm; and finally, monitor and evaluate the views of individuals as expressed within communities.

- Sponsorships constitute a fast-evolving online activity that offers the opportunity of combining aspects of traditional activity sponsorships and media sponsorships and thereby extending marketing strategies in new directions. ${ }^{32}$ If the content sponsored is 
relevant to the brand, attributes can be added to the brand. As an example, Cracknell ${ }^{33}$ uses the sports website sportinglife.com, which promotes itself as innovative, immediate and authoritative. A sponsor for the site could transfer these values to its brand.

- Viral marketing is deliberate spreading of a message through online word-of-mouth. ${ }^{34}$ Viral marketing can be carried by multiple 'agents', eg email, streaming video and audio, games, programmes, websites, pictures or simple documents. Email is used on a regular basis by most online audiences and is therefore an obvious choice for viral marketing. Due to its narrative capabilities, video is also an obvious carrier of viral content.

- Events have become a viable online communication activity with the rapid adoption of broadband. Online events could be product launches, training, seminars, presentation of financial statements, press conferences etc. For an online music retailer, an obvious possibility is online concerts, as arranged by CD-Now and CD Universe with great success. ${ }^{35}$ Another example is women's clothing retailer, Victoria's Secret; the first time an online fashion show was arranged, 1.2 million visitors stopped by, and the web server broke down. ${ }^{36}$

- Sales promotion includes competitions, coupons, samples, contests and sweepstakes. It can be used to aid sales, encourage involvement and repeated access. ${ }^{37}$ According to Kitchen and de Pelsmacker, ${ }^{38}$ more than 30 per cent of the web population are using online coupons. A 2003 Jupiter Research report states that contests and sweepstakes are the sixth most popular online activity, with 52 per cent of online adults regularly participating. ${ }^{39}$

- Affiliate programmes, where a link to the marketer's website is placed on the site of a host business. The host earns a commission, whenever a visitor clicks the link and carries out a transaction with the sponsor. ${ }^{40}$ Affiliates are commonly paid based on the number of leads converted into customers, pay-per-conversion, or by number of leads referred, pay-per-lead. ${ }^{41}$

- E-learning is to a fair extent replacing face-to-face classroom instruction in a growing number of businesses. ${ }^{42}$ Learning management systems can include any kind of multimedia content, synchronous as well as asynchronous communication, all linked together and personalised. ${ }^{43}$

- Email direct marketing might be the one online marcom tool that has had the highest penetration among marketers. Compared with offline direct marketing, online direct marketing allows customisation, personalisation and niche targeting in a much more flexible, easy, quick and cheap way than offline. ${ }^{44}$ A Yesmail study concludes that targeted email can triple the response rate. ${ }^{45,46}$ Along the same line, a study by Ansari and Mela ${ }^{47}$ concludes that email targeting using the users' clickstream information could enhance response by 60 per cent.

- Microsites are smaller websites developed for a specific purpose, such as a product launch or specific campaign. ${ }^{48}$ The overall aim of microsites is, in comparison with corporate websites, not information but rather to involve the user by a high degree of interactivity.

- Mobile location-based services are direct messages that not only are customised in content but also according to a specific location. Strauss ${ }^{49}$ gives the example of receiving a promotional message on your mobile device while passing by your favourite restaurant. Permission and acceptance are core issues that are fundamental to recognise 
in connection with context-based services; respect of user privacy and clear opt-in will be the way to follow. $^{50-51}$

- Games, often referred to as advergaming, ${ }^{52,53}$ demand a high degree of interaction and involvement by nature and therefore not only generate awareness and preferences, but increase the engagement with the brand as well. ${ }^{54}$

- Communities are 'voluntary associations of people with shared interests or common purposes'. ${ }^{55}$ From a technical point of view, online communities can take on many forms, such as multi-user domains, often referred to as forums, and internet relay chat. ${ }^{56-57}$ All types of online communities can be employed within marketing communication. There is reason to believe in a positive association between market performance and the deployment of virtual communities. ${ }^{58}$

- Personalisation can be carried out in more or less advanced ways. One approach is to use manual decision-making systems based on user demographics collected through registration. More advanced methods use automated web usage mining systems that deliver personalised content and services. ${ }^{59-60}$

- SMS was not intended either for heavy personal communications or for mobile marketing, even though the adoption has been explosive. SMS has already proven its effectiveness in online marcom, both as an individual element and integrated with television. ${ }^{61}$ In addition, multimedia message service is beginning to increase its speed of adoption. $^{62}$

- Mobile phone homepages have been adopted very slowly in Europe and the USA. In contrast, the mobile internet has been adopted very fast in Japan. ${ }^{63}$ It is expected that diffusion will accelerate in coming years as technology matures and marketers open their eyes to the advantages of mobile communication. ${ }^{64-66}$

The five measures used in relation to $\mathrm{H}_{3}$, ie the usage of specific systematic methods for prioritisation of online marcom, were derived from 11 interviews with experts in the industry and from the literature as mentioned below. The interviews included media planning agency professionals, communication consultants and marketing and media managers from major companies. None of the measures are unique to online marcom although, for instance, return on investment may be argued to have a better applicability online due to the tracking friendliness of much online communication. On the other hand, reach and frequency measures are heavily rooted in offline advertising. Only the use of methods for online marcom prioritisation was addressed in the questioning.

\section{- Return on investment (ROI) or even} return on marketing/media investment $(\mathrm{RO}(\mathrm{M}) \mathrm{I})$ has been widely adopted by marketers. ${ }^{67-68}$ Even more advanced methods involving econometrics have found their way into ROI measurement. ${ }^{69-2}$

- Reach and frequency is a fundamental media planning tool, even though it is mostly applied to advertising. ${ }^{73,74}$ However, the principle has also been applied to a wider range of media. ${ }^{75,76}$

- Brand equity has been promoted and described by multiple authors. ${ }^{77-80}$ Even though these measures generally only tell firms how they perform and not which disciplines to prioritise, they could serve as an important planning tool.

- Media habits and preferences have already proven to be an important factor in 
Table 1: Differences in importance of offline activities between $B 2 C$ and B2B companies

\begin{tabular}{llllll}
\hline Offline activities & $\begin{array}{l}\text { B2C } \\
\text { Mean }\end{array}$ & SD & $\begin{array}{l}\text { B2B } \\
\text { Mean }\end{array}$ & SD & $\begin{array}{l}\text { Significance } \\
(\boldsymbol{p})\end{array}$ \\
\hline Advertising & 4.19 & 0.98 & 2.48 & 1.42 & 0.00 \\
Sales promotion & 3.81 & 1.13 & 3.58 & 1.10 & $\mathrm{~ns}$ \\
Direct marketing & 3.31 & 1.35 & 3.43 & 1.13 & $\mathrm{~ns}$ \\
Sponsorships & 2.69 & 1.29 & 2.42 & 1.15 & $\mathrm{~ns}$ \\
Public relations & 3.88 & 1.03 & 3.50 & 1.13 & $\mathrm{~ns}$ \\
Events and exhibitions & 3.08 & 1.06 & 3.78 & 1.03 & 0.00 \\
Relationship marketing & 3.08 & 1.35 & 3.80 & 1.06 & 0.00 \\
Point-of-purchase marketing & 3.00 & 1.32 & 2.62 & 1.29 & $\mathrm{~ns}$ \\
Sales supporting activities & 3.77 & 1.21 & 4.35 & 1.01 & 0.03 \\
\hline
\end{tabular}

All questions are measured on a five-point Likert scale. Non-significant (ns) for $p>0.1$

earlier studies, because consumers simply have strong attitudes toward different media and their capabilities. ${ }^{81,82}$ Thus, the target audience's media habits and preferences are also counted as an important prioritisation criteria by practioners. ${ }^{83}$

- Collected experiences as earlier conducted ad hoc effectiveness measurements or just personal experiences are often and should naturally be used as prioritisation parameters.

\section{RESULTS}

As can be observed in Table 1, there are unsurprisingly offline disciplines distinguishing $\mathrm{B} 2 \mathrm{C}$ from $\mathrm{B} 2 \mathrm{~B}$ companies. $\mathrm{B} 2 \mathrm{C}$ companies put relatively more focus on advertising being the predominant mass communication activity. On the other hand, B2B companies prefer more targeted and personal activities in the shape of events and exhibitions, relationship marketing and sales support activities.

As hypothesised, the same pattern was to some extent also found within online marcom. As can be seen in Table 2, B2C companies put significantly more emphasis on display advertising, sales promotion and games (advergaming), whereas online events such as product demonstrations are the only significant discipline for $\mathrm{B} 2 \mathrm{~B}$ companies compared with B2C. Personal and much targeted activities like e-learning, mobile location-based services, communities and personalisation would have been expected to show significantly higher importance for $\mathrm{B} 2 \mathrm{~B}$ companies.

The data were further analysed for overall discrimination. Regarding the online data, Wilks' lambda was significant in the canonical discriminant function $(p=0.023)$. However, Box-M was also highly significant, thereby indicating that the data were not appropriate for discriminant analysis. Additionally, for the offline marcom measures, Wilks' lambda was significant in the canonical discriminant function $(p<0.001)$. However, Box-M was highly significant again. In general, Box-M is often significant, when samples are disproportionate in size, and when the mean values are in fact equal. ${ }^{84}$ As the sample at hand is rather disproportionate in size, logistic regression was applied to see whether discrimination would show up. For the online data, moderate Cox and Snell $\mathrm{R}^{2}(0.215)$ and Nagelkerke $\mathrm{R}^{2}(0.344)$ were found. Further, the Hosmer-Lemeshow test was highly non-significant $(p=0.232)$. For the offline data, as was the case for the 
Table 2: Differences in importance of online activities between $\mathrm{B} 2 \mathrm{C}$ and $\mathrm{B} 2 \mathrm{~B}$ companies

\begin{tabular}{llllll}
\hline Online activities & $\begin{array}{l}\text { B2C } \\
\text { Mean }\end{array}$ & SD & $\begin{array}{l}\text { B2B } \\
\text { Mean }\end{array}$ & SD & $\begin{array}{l}\text { Significance } \\
(\boldsymbol{p})\end{array}$ \\
\hline Display advertising & 2.54 & 1.24 & 1.99 & 0.99 & 0.04 \\
Search engine advertising/marketing & 3.31 & 1.35 & 3.23 & 1.17 & $\mathrm{~ns}$ \\
Public relations & 2.75 & 1.33 & 2.81 & 1.13 & $\mathrm{~ns}$ \\
Sponsorships & 1.28 & 0.46 & 1.54 & 0.84 & $\mathrm{~ns}$ \\
Viral marketing & 1.87 & 1.22 & 1.83 & 0.96 & $\mathrm{~ns}$ \\
Events & 1.63 & 0.82 & 2.09 & 1.12 & 0.02 \\
Sales promotion & 2.20 & 1.32 & 1.62 & 0.93 & 0.01 \\
Affiliate programmes & 2.12 & 1.39 & 1.99 & 1.09 & $\mathrm{~ns}$ \\
E-learning & 1.92 & 1.02 & 2.27 & 1.18 & $\mathrm{~ns}$ \\
Email direct marketing & 2.73 & 1.40 & 2.88 & 1.31 & $\mathrm{~ns}$ \\
Microsites & 2.92 & 1.64 & 2.57 & 1.35 & $\mathrm{~ns}$ \\
Mobile location-based services & 1.43 & 0.95 & 1.74 & 1.09 & $\mathrm{~ns}$ \\
Games & 1.73 & 1.37 & 1.23 & 0.66 & 0.01 \\
Communities & 1.36 & 0.76 & 1.63 & 0.88 & $\mathrm{~ns}$ \\
Personalisation & 2.27 & 1.28 & 2.48 & 1.34 & $\mathrm{~ns}$ \\
SMS/MMS & 1.36 & 0.91 & 1.25 & 0.57 & $\mathrm{~ns}$ \\
Mobile phone homepages & 1.04 & 0.20 & 1.18 & 0.58 & $\mathrm{~ns}$ \\
\hline
\end{tabular}

Note: All questions are measured on a five-point Likert scale. Non-significant (ns) for $p>0.1$

$\mathrm{MMS}=$ multimedia message service

Table 3: Share of total marcom budget spent online and expected spending in five years

\begin{tabular}{|c|c|c|c|c|c|}
\hline Online spending & $\begin{array}{l}\text { B2C } \\
\text { Mean }\end{array}$ & SD & $\begin{array}{l}\text { B2B } \\
\text { Mean }\end{array}$ & SD & $\begin{array}{l}\text { Significance } \\
\text { (p) }\end{array}$ \\
\hline Share of budget spent online & 1.96 & 0.92 & 2.63 & 1.63 & 0.05 \\
\hline Share of budget in 5 years & 3.60 & 1.32 & 4.34 & 2.03 & 0.09 \\
\hline
\end{tabular}

Questions are measured on an 11-point scale with increasing budget percentage intervals.

discriminant analysis, even stronger indicators were found. Cox and Snell $\mathrm{R}^{2}$ was 0.318 and Nagelkerke $\mathrm{R}^{2}$ was 0.508. The Hosmer-Lemeshow test $(p=0.940)$ was highly non-significant. For the online data, however, only two measures were significant (display advertising and sales promotion). The same was the case for the offline measures, where only advertising and sales supporting activities were significant. Overall discrimination between B2C and B2B companies' rating of offline as well as online marcom disciplines could not be established. However, the small sample size and the disproportionate group sizes might have strongly biased the result, and further research should be conducted to enable more definitive conclusions.
As the metrics for both discriminant analysis and logistic regression indicate, offline marcom seems to have a stronger discrimination tendency than the online variant. This is further supported by the individual tests listed in Tables 1 and 2 . This makes it plausible that B2B companies have a less specialised approach when using online marcom than when using offline marcom, and that holistic planning and prioritising methods therefore might be even more essential within online marcom than previously thought.

Table 3 supports $\mathrm{H}_{2 \mathrm{a}}$ and $\mathrm{H}_{2 \mathrm{~b}}$. The mean for $\mathrm{B} 2 \mathrm{C}$ companies is very close to 2 (5-10 per cent of budget spent online), and $\mathrm{B} 2 \mathrm{~B}$ companies are on average spending closer to 3 (11-20 per cent). $\mathrm{B} 2 \mathrm{~B}$ companies are expecting to increase the online marcom share to an mean 
Table 4: Usage of systematic methods for prioritisation of online marcom

\begin{tabular}{llllll}
\hline & $\begin{array}{l}\text { B2C } \\
\text { Mean }\end{array}$ & SD & $\begin{array}{l}\text { B2B } \\
\text { Mean }\end{array}$ & SD & $\begin{array}{l}\text { Significance } \\
(\boldsymbol{p})\end{array}$ \\
\hline Use methods for online prioritisation & 2.96 & 0.98 & 2.37 & 1.17 & 0.02 \\
ROI & 2.50 & 1.47 & 2.40 & 1.32 & $\mathrm{~ns}$ \\
Reach/frequency & 3.24 & 1.39 & 2.51 & 1.36 & 0.02 \\
Brand equity & 1.72 & 0.94 & 1.84 & 1.10 & $\mathrm{~ns}$ \\
Media habits and preferences & 2.67 & 1.37 & 2.37 & 1.32 & $\mathrm{~ns}$ \\
Collected experience & 3.28 & 1.40 & 2.90 & 1.17 & $\mathrm{~ns}$ \\
\hline
\end{tabular}

All questions are measured on a five-point Likert scale. Non-significant (ns) for $p>0.1$

higher than 4 (21-30 per cent) in the future, whereas $\mathrm{B} 2 \mathrm{C}$ intend to increase their spending to a mean value well below 4. This means that $\mathrm{B} 2 \mathrm{C}$ companies in five years' time will also spend significantly less than $\mathrm{B} 2 \mathrm{~B}$ companies.

That $\mathrm{B} 2 \mathrm{~B}$ companies in particular spend a large part of their budget online, emphasises the need for systematic planning and prioritisation methods within $\mathrm{B} 2 \mathrm{~B}$ online marcom.

Table 4 supports $\mathrm{H}_{3}$, as $\mathrm{B} 2 \mathrm{C}$ has a significantly higher usage of systematic methods for online marcom prioritisation. On the individual method measures, there is only a significant difference in the usage of reach and frequency, which is in line with B2C companies' higher focus on advertising. Further, all measures were tested against the neutral scale value 3 . For B2B companies, both the overall statement as well as all individual methods' measures, except for 'collected experience', is significantly lower $(p<0.001)$ than the neutral scale value. For B2C companies only the use of 'brand equity' as prioritisation method is significantly lower than the neutral scale value. This makes it likely that as B2C companies use their existing available systematic methods, they do not necessarily have the same need for new methods as B2B companies, which mostly rely on subjective and ad hoc collected experiences.

\section{CONCLUSIONS, LIMITATIONS AND MANAGERIAL IMPLICATIONS}

B2B companies spend a significantly larger part of their marcom budget online than $\mathrm{B} 2 \mathrm{C}$ companies, and this difference is still expected to exist in five years' time. The use of online marcom, particularly in B2B companies, has reached a level where better and more holistic prioritisation and planning methods are needed. If the expected online $\mathrm{B} 2 \mathrm{~B}$ spending materialises, then the discrimination between $\mathrm{B} 2 \mathrm{C}$ and $\mathrm{B} 2 \mathrm{~B}$ on usage of methods for online marcom prioritisation will hopefully also be reduced. There is, however, call for research within the area, as none of the existing methods seem to make a perfect fit for B2B companies.

Even though a clear overall discrimination between $\mathrm{B} 2 \mathrm{~B}$ and $\mathrm{B} 2 \mathrm{C}$ companies' attitudes towards the importance of marcom disciplines could not be established, significant differences in individual disciplines were found. Where B2C companies find offline advertising significantly more important, $\mathrm{B} 2 \mathrm{~B}$ companies prefer targeted and personalised disciplines like events and exhibitions, relationship marketing and sales support activities. Regarding online communication, B2C companies also put significantly more focus on mass communication disciplines like display advertising, sales promotion and games 
(advergaming). However, B2B companies only put significantly more focus on online events such as product demonstrations. Personal and targeted disciplines like e-learning, mobile location-based services, communities and personalisation did not show significant differences between B2C and B2B.

Summing up, the overall discrimination tendency between B2C and B2B seems stronger offline than online, indicating that, B2B companies might have a less specialised approach when using online marcom compared with offline marcom. This suggests that B2B companies should look for holistic online marcom planning and prioritising methods. As it is today, B2C companies have a significantly higher usage of systematic methods for online communication prioritisation. This seems to be caused by a high focus on advertising media, which enables them to adopt existing offline media planning traditions, whereas $\mathrm{B} 2 \mathrm{~B}$ companies do not seem to have their needs for a systematic and holistic prioritisation method fulfilled by any existing instrument.

This research is based on a very small sample in a geographically limited market, and the results should therefore be crosschecked by a larger sample, preferably in more geographically extensive markets. Still, the paper stresses the need for $\mathrm{B} 2 \mathrm{~B}$ marketers to be on the lookout for better prioritisation and planning methods for their online marketing communication. As an example, such an instrument could be based on customer preferences, eg conjointly measured preferences for different disciplines/activities and the different channels available. Conjoint analysis, for example, could give the answers to, say, how important newsletters compare with sales meetings or how recipients value email compared with postal delivery as a channel for newsletter delivery. Indeed, Green and Srinavasan ${ }^{85}$ did foresee conjoint analysis to be an instrument for future marcom prioritisation in their 1990 major conjoint analysis review in Journal of Marketing. Now, more than 15 years later, it has perhaps become even more important.

\section{References}

1 Stein, G. (2005) 'Integrated Marketing: Using Real-time Data is Key to Success', Vision Report, Jupiter Research.

2 Hansen, F., Bach Lauritsen, G. and Grønholdt, L. (2001) 'Communication and Media Planning (Kommunikation, mediaplanlægning og reklamestyring. Bind 1 metoder og modeller)', Samfundslitteratur, Copenhagen.

3 Grönross, C. (1994) 'From marketing mix to relationship marketing: Towards a paradigm shift in marketing,, Asia-Australia Journal of Marketing, Vol. 2, No. 1, pp. 9-30.

4 Jensen, M. B. and Jepsen, A. L. (2006) 'Online marketing communications: need for a new typology for IMC?' In 'Contemporary Issues in Corporate and Marketing Communications: Towards a Socially Responsible Future', Pristop, Ljubljana, Slovenia, pp. 133-144.

5 Barwise, P. and Farley, J. U. (2005) 'The state of interactive marketing in seven countries: Interactive marketing comes of age', Journal of Interactive Marketing, Vol. 19, No. 3, pp. 67-80.

6 Hansen, ref. 2 above.

7 Hair, J. F., Anderson, R. E., Tatham, R. L. and Black, W. C. (1998) 'Multivariate Data Analysis', Prentice-Hall, Upper Saddle River, NJ.

8 Lattin, J., Carroll, J. D. and Green, P. E. (2003) 'Analyzing Multivariate Data', Thomson, London.

9 Pickton, D. and Broderick, A. (2004) 'Integrated Marketing Communications', Pearson Higher Education, London.

10 Pelsmacker, P. D., Geuens, M. and Van den Bergh, J. (2001) 'Marketing Communications', Financial Times Prentice Hall, London.

11 Belch, G. E. and Belch, M. A. (2004) 'Advertising and promotion an integrated marketing communications perspective', McGraw-Hill, Boston.

12 Duncan, T. (2002) 'IMC Using Advertising and Promotion to Build Brands', McGraw-Hill, London.

13 Kitchen, P. J. (1999) 'Marketing Communications Principles and Practice', International Thomson Business Press, London.

14 Kitchen, P. J. and de Pelsmacker, P. (2004) 'Integrated Marketing Communication: A Primer', Taylor and Francis Ltd, London.

15 Delozier, M. W. (1978) 'Marketing Communications Process', McGraw-Hill, London.

16 Ibid.

17 Jensen and Jepsen, ref. 4 above. 
18 Pickton and Broderick, ref. 9 above.

19 Pelsmacker et al., ref. 10 above.

20 Belch and Belch, ref. 11 above.

21 Duncan, ref. 12 above.

22 Kitchen and de Pelsmacker, ref. 14 above.

23 Strauss, J., El-Ansary, A. and Frost, R. (2003)

'E-Marketing', Pearson Higher Education, New Jersey.

24 Roberts, M. L. (2003) 'Internet marketing Integrating online and offline strategies', McGraw-Hill Education - Europe, London.

25 Jensen, M. B. and Fischer, L. H. (2004) 'E-branding', Gyldendal, Copenhagen.

26 Briggs, R. (2002) 'Cross-media measurement' in 'Online Audience Conference', ESOMAR, Cannes, pp. 199-228.

27 Swinfen-Green, J. (2002) 'Online branding: the retreat from euphoria', Admap, No. 424, January, p. 15.

28 Nail, J. (2002) 'When Online Branding Works', TechStrategy Report, Forrester Research.

29 Seda, C. (2004) 'Search Engine Advertising Buying Your Way to the Top to Increase Sales', Macmillan Computer Publishing, Indianapolis, IN.

30 Smith, J. (2005) 'European Online Media Sales: Advertisers' Interest in Behavioral Targeting Offers Publishers Opportunities', Concept Report, Jupiter Research, London, UK.

31 Macleod, S. (2000) 'The evaluation of PR on the internet', Journal of Communication Management, Vol. 5, No. 2, pp. 179-188.

32 Drennan, J.C. and Cornwell, T. B. (2004) 'Emerging strategies for sponsorship on the internet', Journal of Marketing Management, Vol. 20, No. 9/10, pp. 1123-1146.

33 Cracknell, M. (2001) 'Digital sports sponsorship: a marriage made in heaven', Sports Marketing, No. 74, September, pp. iv-v.

34 Barratt, S. (2001) 'Viral ads can extend brand reach', Revolution, 14 November.

35 Duncan, ref. 12 above.

36 Strauss et al., ref. 23 above.

37 Pickton and Broderick, ref. 9 above.

38 Kitchen and de Pelsmacker, ref. 14 above.

39 Whitney, D. (2003) 'Online sweepstakes pay off for stations', Television Week, Vol. 22, No. 45, p. 16.

40 Papatla, P. and Bhatnagar, A. (2002) 'Choosing the right mix of on-line affiliates: how do you select the best?', Journal of Advertising, Vol. 31, No. 3, pp. 69-81.

41 Libai, B., Biyalogorsky, E. and Gerstner, E. (2003) 'Setting referral fees in affiliate marketing', Journal of Service Research, Vol. 5, No. 4, pp. 303-315.

42 Schweizer, H. (2004) 'E-learning in business', Journal of Management Education, Vol. 28, No. 6, pp. 674-692.

43 Sheng-Tun Li, Chu-Hung Lin and Pao-Ta Yu. (2005) 'On a design of SCORM-compliant SMIL-enabled multimedia streaming e-learning system', International Journal of Distance Education Technologies, Vol. 3, No. 3, pp. 48-64.

44 Kitchen and de Pelsmacker, ref. 14 above.
45 Taylor, C.P. and Neuborne, E. (2002) 'Getting personal', Adweek New England Edition, Vol. 39, No. 44, p. IQ1.

46 Customer Interface (2002) 'Message personalization: targeting delivers higher response, retention', Vol. 15, Sep/Oct, p. 17.

47 Ansari, A. and Mela, C.F. (2003) 'E-customization', Journal of Marketing Research, Vol. 40, No. 2, pp. 131-145.

48 Kitchen and de Pelsmacker, ref. 14 above.

49 Strauss et al., ref. 23 above.

50 Barnes, S. J. and Scornavacca, E. (2004) 'Mobile marketing: the role of permission and acceptance', International Journal of Mobile Communications, Vol. 2, No. 2, pp. 128-139.

51 Kavassalis, P., Spyropoulou, N., Drossos, D., Mitrokostas, E., Gikas, G. and Hatzistamatiou, A. (2003) 'Mobile permission marketing: framing the market inquiry', International Journal of Electronic Commerce, Vol. 8, No. 1, pp. 55-79.

52 Garcia, D. (2004) 'Media Research Report: Advergaming Gets Consumers to Play While Advertisers Pay', Gartner Inc, New York, NY.

53 Lee, V. (2003) 'Advergaming' your way to online brand building successes', Media Asia, 5 September, p. 15.

54 Garcia, ref. 52 above.

55 Rheingold, H. (1993) 'The Virtual Community Homesteading on the Electronic Frontier', Addison Wesley, Reading.

56 Trabak, A. (2000) 'The rise and power of online communities in the network economy', in 'Impact of Networking', ESOMAR, Vienna, pp. 415-427.

57 Smith, M. A. and Kollock, P. (1999) 'Communities in Cyberspace', Routledge, London.

58 Brown, S. L., Tilton, A. and Woodside, D. M. (2002) 'The case for online communities', Web exclusive, The McKinsey Quarterly, www.mckinseyquarterly.com/article_abstract_ visitor.aspx?ar=1143\&L2=16\&L3=44.

59 Mobasher, B., Cooley, R. and Srivastava, J. (2000) 'Automatic personalization based on web usage mining', Communications of the ACM, Vol. 43, No. 8, pp. 142-151.

60 Shahabi, C. and Banaei-Kashani, F. (2003) 'Efficient and anonymous web-usage mining for web personalization', Journal on Computing, Vol. 15, No. 2, pp. 123-147.

61 Rettie, R., Grandcolas, U. and Deakins, B. (2005) 'Text message advertising: Response rates and branding effects', Journal of Targeting, Measurement and Analysis for Marketing, Vol. 13, No. 4, pp. 304-312.

62 Customer Interface, ref. 46 above.

63 Ishii, K. (2004) 'Internet use via mobile phone in Japan', Telecommunications Policy, Vol. 28, No. 1, pp. 43-58.

64 Reynolds, P. (2003) 'A vision of the internet in 2010', Campus-Wide Information Systems, Vol. 20, No. 4, pp. 125-128.

65 Steinbock, D. (2005) 'Seeing is believing', Communication World, Vol. 22, No. 6, pp. 19-12.

66 Steinbock, D. (2003) 'Globalization of wireless value 
system: from geographic to strategic advantages', Telecommunications Policy, Vol. 27, No. 3/4, pp. 207-236.

67 Lenskold, J. (2003) 'Marketing ROI: The Path To Campaign, Customer, and Corporate Profitability', McGraw-Hill, New York.

68 Powell, G. R. (2003) 'Return on Marketing Investment: Demand More from Your Marketing and Sales Investments', RPI Press, USA.

69 Cook, L. (2004) 'Econometrics and integrated campaigns', Admap, No. 451, June, pp. 37-40.

70 Hollis, N. (1994) 'The link between television ad awareness and sales: New evidence from sales response modelling, Journal of the Market Research Society, Vol. 36, No. 1, pp. 41-55.

71 McDonald, C. (2004) 'Market models and modelling', Admap, September, pp. 12-13.

72 Saunders, J. (editor) (2004) 'The Communications Challenge', The Account Planning Group, UK.

73 Hansen et al., ref. 2 above

74 Leckenby, J. D. and Kuen-Hee Ju. (1989) 'Advances in media decision models', Current Issues and Research in Advertising, Vol. 12, No. 2, pp. 311-358.

75 Leckenby, J. D. and Hong, J. (1998) 'Using reach/frequency for web media planning', Journal of Advertising Research, Vol. 38, No. 1, pp. 7-21.

76 Hyo-Gyoo Kim, H. G. and Leckenby, J. D. (2003) 'An IMC planning framework using reach and frequency concepts', available at: http://ciadvertising.org/studies/reports/ measurement/IMCPlanning_hgkim.pdf (accessed 26 July, 2006).

77 Aaker, D. A. (2002) 'Building Strong Brands', The Free Press, New York.

78 Keller, K. L. (2003) 'Strategic brand management building, measuring, and managing brand equity', Pearson Higher Education, New Jersey.

79 Keller, K. L. (2001) 'Building Customer-Based Brand Equity: A Blueprint for Creating Strong Brands', Marketing Science Institute, Cambridge, MA.

80 Martensen, A. and Grønholdt, L. (2004) 'Building Brand Equity A Customer-Based Modelling Approach', Journal of Management Systems, Vol. 16, No. 3, pp. 37-51.

81 Stephens, N. (1981) 'Media use and media attitude changes with age and with time', Journal of Advertising, Vol. 10, No. 1, pp. 38-47.

82 Larkin, E.F. (1979) 'Consumer perceptions of the media and their advertising content', Journal of Advertising, Vol. 8, No. 2, pp. 5-48.

83 Saunders, ref 72 above.

84 Green, P. E. (1978) 'Analyzing Multivariate Data', Dryden Press, Hinsdale, IL.

85 Green, P. E. and Srinivasan, V. (1990) 'Conjoint analysis in marketing: New developments with implications for research and practice', Journal of Marketing, Vol. 54, No. 4, pp. 3-20. 